\title{
INTERACTION BETWEEN ROD AND CONE SYSTEMS IN DICHOPTIC VISUAL MASKING ${ }^{\star}$
}

\author{
DAVID H. FOSTER and ROBERT J. MASON
}

Department of Communication, University of Keele, Keele, Staffo 'dshire ST5 5BG (Great Britain)

(Received November 11.th, 1976)

(Accepted November 19th, 1976)

\section{SUMMARY}

The brightness of a brief flash of ligh: is reduced by the suitable presentation of a second flash in an adjacent region of the visual field. This masking effect (metacontrast) can be induced dichoptically, that is with the test flash presented to one eye and the rrasking flash to the other. By 3 suitable choice of wavelengths and conditioning ileld, the test flash may be arranged to effectively stimulate only rod receptors and the masking flash only cone receptors. A dichoptic masking effect is still obtained.

The rod and cone receptor mechanis ms of the human visual system function independently in dark-adaptation and certain increment threshold measurements $[8,16,19,29,22]$. Interaction between the two receptor systems has, however, been demonstrated in other increment thr ashold determinations $[7,12]$, in the production of some chromatic effects $[1 £, 1.7,23]$, in the cancellation of mesopic flicker [11] and in a particular movement illusion [6] . Fcr the visual masking effect known as metacontrast $[1,9,18]$, where the brightness of a lash of light is reduced if it is followed a short time later by a secund flash to an adjacent region of the retina, daia showing both rod-cone independence [2] and rod-cone interaction [5] have been obtainer. These studies have used monoptic stimulation, that is, both test ais rasking flashes presented to the same eye. The present work is concern':d with rod-cone inter xction when the metacontrast is produced by dichoptic stimulaticn, that is, the test flash presented to one eye and the masking flash to the other [see refs. 10,14 and 21]. Evidence that under such conditions the metacontrast is not specific to a particular class of receptor has already been reported [24].

- The experiments reported here were carried out while the authore were in the Department of Physics, Imperial College of Science and Technology, Lonion, Great Britain. 
Apparatus and methods used here are similar to those employed in an earlier investigation into monoptic metacontrast [5]. The stimuli were produced by a standard 3-channel Maxwellian-view optical system. The disc-shaped test flash (diameter $1.1^{\circ}$ ) was presented to the left eye and the annular masking fiash (i.d. $2.3^{\circ}$, o.d. $4.2^{\circ}$ ), superimposed on a steady annular conditioning field (i.d. $1.6^{\circ}$, o.d. $5.0^{\circ}$ ), presented to the right eye. Separate fixation targets were provided for each eye. When viewed dichoptically, the stimuli appeared concentric and centered about a point $4.0^{\circ}$ to the right of the foveally fused target. The durations of the test and masking flashes, controlled by electromagnetic shutters, were each $10 \mathrm{msec}$. The subject used a dental bitebar and viewed the stimuli through $2-\mathrm{mm}$ artificial pupils.

The experiment was carried out under dark-adapted conditions. The masking flash was red, the conditioning annulus blue and the test flash green. The spectral compositions of the stimuli were determined, respectively, by a long pass gelatin filter (Ilford, No. 609; cut-on point $660 \mathrm{~nm}$ ), a 465-nm interference filter (Balzers, type B40; peak wavelength $465 \mathrm{~nm}$, half bandwidth $8 \mathrm{~nm}$ ), and a 509-nm interference filter (Balzers, type B40; peak wavelength $509 \mathrm{~nm}$, half bandwidth $9 \mathrm{~nm}$ ). The illumination produced by the conditioning annulus was fixed at 1.6 photopic trolands. The luminance of the superimposec masking flash was adjusted so that when the flash was made green ( $509 \mathrm{~nm}$ ), but given the same scotopic value as the red flash, it was just subliminal. The masking flash thus effectively excited only cones. From preliminary dark-adaptation measurements, the test flash was found at absolute threshold to be $1.5 \mathrm{log}$ units below cone threshold. The test flash thus effectively excited only rods.

For each fixed time-lag between the onsets of the test flash and masking flash, the subject varied the luminance of the test flash with a neutral density wedge until it was just detectable. The final threshold setting was approached from below. Each measurement was preceded and followed by a separate determination of the test-flash threshold without the masking flash. Elevation of test-flash threshold above resting level was specified by the difference between the wedge reading obtained with the masking flash and the mean of the two readings obtained without. The authors acted as observers.

Fig. 1a shows data obtained by subject DHF for a range of onset time-lags. Threshold elevacion of the green test flash is plotted against delay in presentation of the red masking flash. There is a clear masking effect of about 0.2 $\log$ units at 50-100 msec and a similar effect at $350 \mathrm{msec}$. The effects are statistically significant $(P<0.001)$. Threshold elevation recorded by subject RJM at 50 msec was 0.30 log units, which is also significant $(P<0.005)$.

That these elevations in test-flash threshold are indeed a consequence of rod-cone interaction, and not rod-rod interaction, is indicated by the data shown in Fig. 1b. Threshold elevation of the green test flash is plotted against delay in presentation of a green masking flash of the same scotopic luminance as the original red masking flash. If the elevations of Fig. $1 \mathrm{a}$ are the result of pure rod-rod interaction, then this green masking flash should give rise to the same masking effects. In fact, at no onset delay is there any significant 


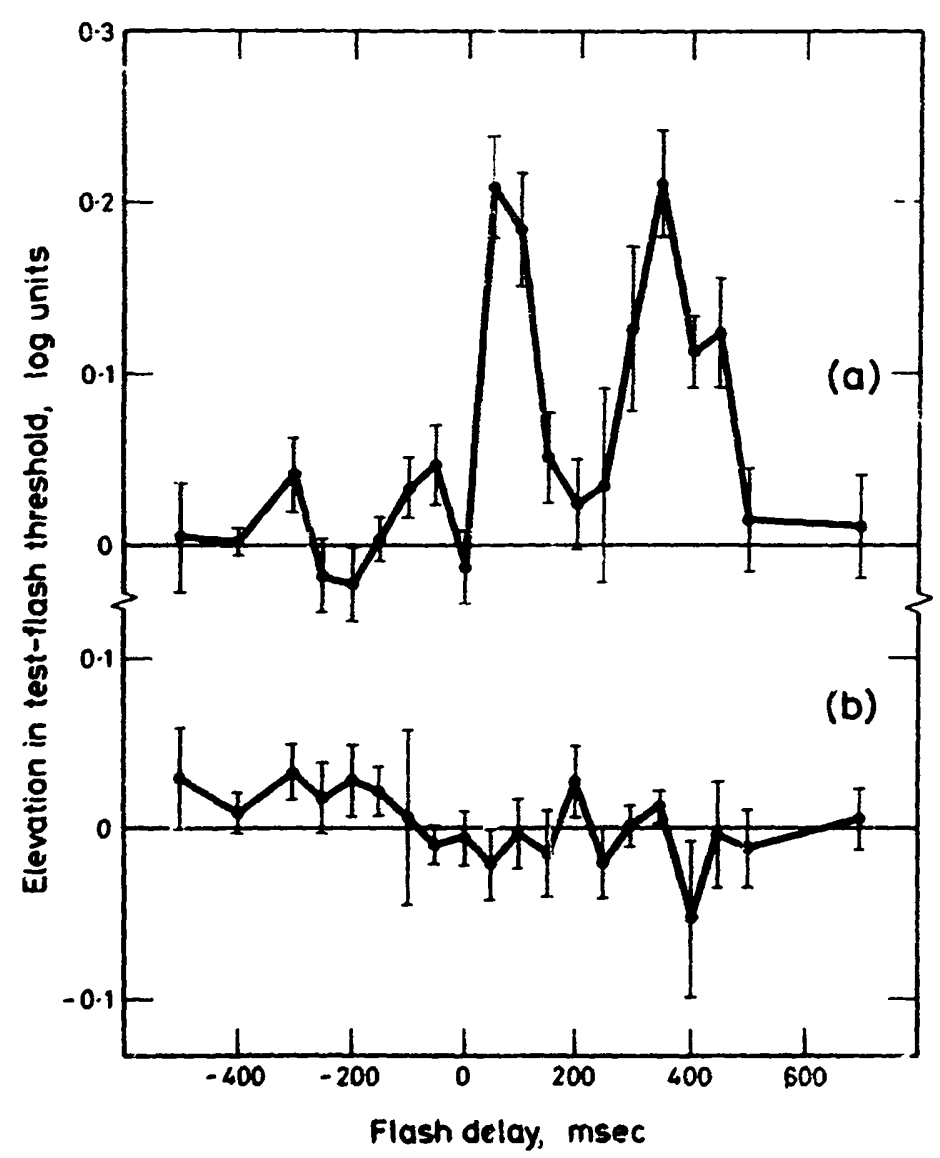

Fig. 1. Elevation in test-flash threshold as a function of delay in presentation of $m$ ssking flash. Data in (a) are for a green (509 nm) test-flash and a red (>660 nm) masking flash; data in (b) are for a green (509 $\mathrm{nm}$ ) test flash and a green $(509 \mathrm{~nm})$ after flash of the same scotopic luminance as the red masking flash. All flash durations were $10 \mathrm{msec}$. Each point represents in (a) the mean of six determinations and in (b) the mean of four determinations. The vertical trars indicate \pm 1 S.E.M. Observer: DHF.

elevation in test-flash threshold $(\bar{P}>0.1)$.

The presence of two maxima in the data of Fig. 1a is not unexpected. In general, if the test and masking flashes excite the same classes of photoreceptor, then with suitable stimulus ccnditions dichoptic masking is found not only at positive masking-fiajh delays (i.e. metacontrast) but also at negative masking-flash delays [10]. In the present case, the time course of the masking effect is shifted towards rnore positive values, which is consistent with the rod-mediated response being delayed with respect to the cone-mediated response. The difference in response latencies, determined by an apparent movement method $[3,15]$, was found for subject DHF to be $94 \pm 4$ msec. Nevertheless, from the displacement of the rod-cone and cone-cone interaction curves in the monoptic situation [5], it seems unlikely that this relative latency is responsible for the whole of the positive shift.

The site of the dichoptic interaction between rod and cone systems, apart from being central to the chiasma, is not immediately anparent, although McFadden and Gummerman [14] have suggested that cichoptic metacontrast 
may be induced by interaction in areas beyond area 17 . Neurophysiological correlates of monoptic metacontrast have been examined in some detail by Bridgernan [4]

\section{REFERENCES}

1 Akpern, M., Letacontrast, J. opt. Soc. Amer., 43 (1953) 648-657.

2 Alpern, M., Rod-cone independence in the after-flash effect, J. Physiol. (Lond.), 176 (1965) 462-472.

3 Arden, G.E. and Weale, R.A., Variations of the latent period of vision, Froc. roy. Soc. B, 142 (1954) 258-267.

4 Bridgeman. B., Correlates of metacontrast in single cells of the cat visual system, Vision Res, 15 (1975) 91-99.

5 Foster, D.H., Rod-cone interaction in the after-flesh effect, Visic n Res., 16 (1976) 393-396.

6 Foster, D.H., Rod- and cone-mediated interactions in the fine-grain movement illusion, Visun Res., in press.

7 Frumkes, T.E., Sekuler, M.D., Barris, M.C., Reiss, E.H. and Chalupa, L.M., Rod-cone interaction in human scotopic visior: -1 . Temporal analysis, Vision Res., 13 (1973) 1269-1282.

8 Hayhoe, M.M. and MacLeod, D.I.A., Rod-cone independence in dark adaptation, Vision Res., 16 (1976) 591-600.

9 Kahneman, D., Method, findings, and theory in studies of visual masking, Psychol. Bull, 70 (1968) 404-425.

10 Kolers, P.A. and Rosner, B.S., On visual masking (metacontrast): dichoptic observation, Amer. J. Psychol., 73 (1960) 2-21.

11 MacLeod, D.I.A., Rods cancel cones in flicker, Nature (Lond.), 235 (1972) 173-174.

12 Makous, W. anci Boothe, R., Cones block signals from rods, Vision Res, 14 (1974) 285--294.

13 McCann, J.J. and Benton, J.L., Interaction of the long-wave cones and the rods to produce color sensations, J. opt. Soc. Amer., 59 (1969) 103-107.

14 McFadden, D. and Gummerman, K., Monoptic and dichoptic metacontrast across the vertical meridian, Vision Res., $13\left(19{ }^{\prime} i 3\right)$ 185-196.

15 Foufs, J.A.J., Dynamic properties of vision - V. Perception lag and reaction time in relation to flicker and flash thresholds, Vision Res., 14 (1974) 853--869.

16 Rushton, W.A.H., Dar-adaptation and the regeneration of rhodopsin, J. Physiol. (Lond.), 156 (1961) 166-178.

17 Stabell, B. and Stabell, U., Rod and cone contributions to peripheral colour vision, Vision Res., 16 (1976) 1099-1104.

18 Stigler, R., Chronophotische Studien uber den Umgebungskontrast, Pnügers Arch. ges. Physiol., 134 (1910) 365-475.

19 Stiles, W.S., Increment thresholds and the mechanisms of colour vision, Docum. ophthal. (Den Haag), 3 (1949) 1.38-163.

20 Stiles, W.S., Colour vision: the approach through increment-threshold sensitivity, Proc. nat. Acad. Sci. (Wash.), 45 (1959) 100-114.

21 Weisstein, N., Metacontrast. In D. Jameson and L.M. Hurvich (Eds.), Handbook of Sensory Physiology, Vol. VII/A, Visual Psychophysics, Springer, Berlin, 1972, pp. 233-272.

22 Westheimer, G., Rod-cone independence for sensitizing interaction in the human retina, J. Physiol. (Lond.), 206 (1970) 109-116.

23 Willmer, E.N., Low threshold rods and the perception of blue, J. Physiol. (Lond.), 111 (1949) $17 \mathrm{p}$.

24 Yellott, J.I., Jr. and Wandell, B.A., Colsur properties of the contrast flash effect: monoptic vs dichoptic comparisons, Vision Res., 16 (1976) 1275--1280. 